Preprint

UCRL-JC-147079

\title{
Liquid Wall Options for Tritium-Lean Fast Ignition Inertial Fusion Energy Power Plants
}

S. Reyes, R.C. Schmitt, J.F. Latkowski, S.G. Durbin, J. Sanz

This article was submitted to $6^{\text {th }}$ International Symposium on Fusion Nuclear Technology, San Diego, CA, April 7-12, 2002

\section{U.S. Department of Energy}

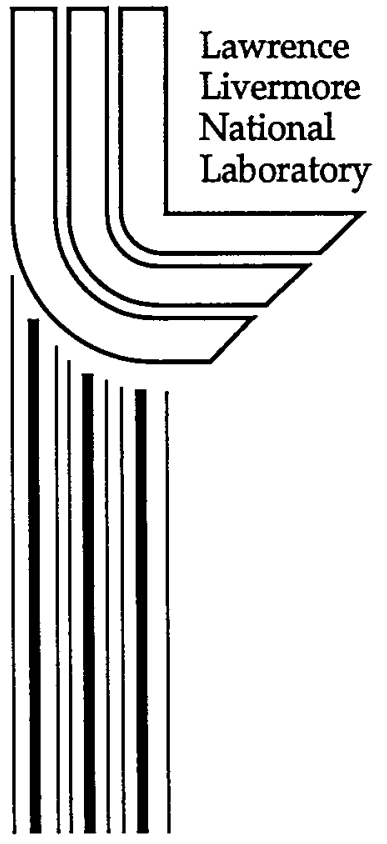

January 17, 2002 


\section{DISCLAIMER}

This document was prepared as an account of work sponsored by an agency of the United States Government. Neither the United States Government nor the University of California nor any of their employees, makes any warranty, express or implied, or assumes any legal liability or responsibility for the accuracy, completeness, or usefulness of any information, apparatus, product, or process disclosed, or represents that its use would not infringe privately owned rights. Reference herein to any specific commercial product, process, or service by trade name, trademark, manufacturer, or otherwise, does not necessarily constitute or imply its endorsement, recommendation, or favoring by the United States Government or the University of California. The views and opinions of authors expressed herein do not necessarily state or reflect those of the United States Government or the University of California, and shall not be used for advertising or product endorsement purposes.

This is a preprint of a paper intended for publication in a journal or proceedings. Since changes may be made before publication, this preprint is made available with the understanding that it will not be cited or reproduced without the permission of the author.

This report has been reproduced directly from the best available copy.

Available electronically at http://www.doc.gov/bridge

Available for a processing fee to U.S. Department of Energy

And its contractors in paper from

U.S. Department of Energy

Office of Scientific and Technical Information

P.O. Box 62

Oak Ridge, TN 37831-0062

Telephone: (865) 576-8401

Facsimile: (865) 576-5728

E-mail: reports@adonis.osti.gov

Available for the sale to the public from

U.S. Department of Commerce

National Technical Information Service

5285 Port Royal Road

Springfield, VA 22161

Telephone: (800) 553-6847

Facsimile: (703) 605-6900

E-mail: orders@ntis.fedworld.gov

Online ordering: http://www.ntis.gov/ordering.htm

\section{OR}

Lawrence Livermore National Laboratory

Technical Information Department's Digital Library

http://www.llnl.gov/tid/Library.html 


\title{
Liquid Wall Options for Tritium-Lean Fast Ignition
}

\section{Inertial Fusion Energy Power Plants}

\author{
S. Reyes ${ }^{1}$, R. C. Schmitt ${ }^{1,2}$, J. F. Latkowski ${ }^{1}$, S. G. Durbin ${ }^{3}$, J. Sanz ${ }^{4}$ \\ ${ }^{1}$ Lawrence Livermore National Laboratory, P. O. Box 808, Mailstop L-641, Livermore, CA 94550 \\ ${ }^{2}$ University of Michigan-Ann Arbor, Department of Nuclear Engineering \\ ${ }^{3}$ Georgia Institute of Technology, Department of Mechanical Engineering \\ ${ }^{4}$ UNED/ ETSII, Dpto. Ingeniería Energética, C/ Ciudad Universitaria s/n, 28040 Madrid, Spain. \\ Also: Instituto Fusión Nuclear, Madrid, Spain
}

\begin{abstract}
In an inertial fusion energy (IFE) thick-liquid chamber design such as HYLIFE-II, a molten-salt is used to attenuate neutrons and protect the chamber structures from radiation damage. In the case of a fast ignition inertial fusion system, advanced targets have been proposed that may be self-sufficient in terms of tritium breeding (i.e., the amount of tritium bred in target exceeds the amount burned). This aspect allows for greater freedom when selecting a liquid for the protective blanket, given that lithiumbearing compounds are no longer required. The present work assesses the characteristics of many single, binary, and ternary molten-salts using the NIST Properties of Molten Salts Database. As an initial screening, salts were evaluated for their safety and environmental (S\&E) characteristics, which included an assessment of waste disposal
\end{abstract}


rating, contact dose, and radioactive afterheat. Salts that passed the S\&E criteria were then evaluated for required pumping power. The pumping power was calculated using three components: velocity head losses, frictional losses, and lifting power. The results of the assessment are used to identify those molten-salts that are suitable for potential liquid-chamber fast-ignition IFE concepts, from both the S\&E and pumping power perspective. Recommendations for further analysis are also made.

\section{Introduction}

The idea of IFE using fast ignition has been proposed as a method of achieving relatively high gain using ultra-powerful lasers to ignite the fusion fuel [1]. Advanced targets have been proposed that may be self-sufficient in tritium breeding [2]. These "tritium-lean" targets contain $\sim 0.5 \%$ tritium and $99.5 \%$ deuterium, but require a large $\rho r$ of $10-20 \mathrm{~g} / \mathrm{cm}^{2}$ compared to $\sim 3 \mathrm{~g} / \mathrm{cm}^{2}$ for conventional hot-spot ignition. About $55 \%$ of the energy released by S. Atzeni's target is produced by D-T reactions, even though the majority of the reactions are D-D, which produces a new surplus of tritium $[1,2,3]$. For a 1 GWe power plant output, and because of the large yield (1330 MJ), these targets could be ignited at a repetition-rate of only $1.7 \mathrm{~Hz}$. The low repetition-rate keeps the pumping power significantly lower than in a traditional $5-10 \mathrm{~Hz}$ system.

Traditionally, when designing a thick-liquid protected IFE chamber such as HYLIFEII [4], a major limitation to the choice of the liquid was the tritium-breeding ratio (TBR). The blanket was required to provide a $T B R \geq 1.1$ so that tritium did not need to be added

to the system during operation. Elimination of this requirement allows for greater 
flexibility in selection of a liquid than ever before. Materials selection may now be based upon other characteristics, such as S\&E, pumping power, corrosion, and vapor pressure, along with others.

In this study we assessed the characteristics of single, binary, and ternary molten-salts as well as several liquid metals. Using the National Institute of Standards and Technology (NIST) Properties of Molten Salts Database [5], approximately 4300 molten-salts were included in the study. Two rounds of analyses were performed and are reported here. Assessments of the S\&E characteristics and of required pumping power were performed for all materials for which density and viscosity data were available.

\section{S\&E Assessment}

Three assessments were done as part of the S\&E study: a calculation of the waste disposal rating (WDR), an analysis of the radioactive afterheat in an accident scenario, and a calculation of the contact dose rate to determine if the material could be recycled. Our analyses assumed a total molten salt inventory of $1250 \mathrm{~m}^{3}$, with approximately 12.5 $\mathrm{m}^{3}(1 \%)$ of the material in the chamber at any given time. All studies were done using the TART Monte Carlo code for neutron transport and the ACAB activation code [6, 7]. Neutron irradiation was assumed to occur for 30 full-power years.

The WDR index has been used in order to classify the method of waste disposal needed [8]. If the WDR $\leq 1$, the material can be disposed of via shallow land burial. Given the potentially large waste volumes involved, disposal via shallow land burial is a primary goal, and thus, liquids with a WDR $>1$ were eliminated from consideration. 
In the case of a severe accident, the radioactive afterheat of the liquid could heat the chamber wall and increase the quantity of material mobilized and released to the environment. Here, we compare the afterheat of the liquid to that from the chamber itself (assumed to be type 304 stainless steel, as in HYLIFE-II). In previous work [9], we calculated the temperature evolution of the HYLIFE-II first wall during a loss of coolant accident. It was observed that in order to keep the SS304 below its melting temperature $\left(\mathrm{T}_{\text {melt }} \sim 1400^{\circ} \mathrm{C}\right)$, the integrated afterheat should be below $2.33 \cdot 10^{9} \mathrm{~W}$ at a time of 7 days after accident initiation.

Finally, we require that candidate liquids would qualify for remote recycling. We assume that this requirement is satisfied if the component's contact dose limit is $<0.1$ $\mathrm{Sv} / \mathrm{hr}$ within 50 years of decay. While hands-on recycling is desirable, it requires a significantly lower contact dose rate of $<25 \mu \mathrm{Sv} / \mathrm{hr}$, which may be overly restrictive.

In order to perform a preliminary screening of the initial 4300 molten-salts, we established allowable density limits for each element based upon the above S\&E criteria. If all of the elements in a particular material were below these limits, the material passed the S\&E assessment. Table I shows the acceptable quantities of each particular element in a molten-salt, and which criterion limits the acceptability. For example, the allowable densities of $\mathrm{Li}, \mathrm{Be}$ and $\mathrm{F}$ are all much higher than their elemental densities in flibe, and thus, flibe would be an acceptable liquid. After assessing S\&E characteristics, approximately 200 liquids remained-mostly single-salts and binaries. These were then evaluated for required pumping power.

\section{Pumping Power Assessment}


In the case of a thick-liquid based fusion concept, pumping power can be an important contributor to the power plant's recirculating power fraction. In order to have an attractive cost of electricity, this fraction must be maintained at a reasonable level. For the purposes of this study, a pumping power limit of $80 \mathrm{MW}$ was assumed. Three components to pumping power must be considered: velocity head, frictional/minor losses in pipes, and lifting power.

\section{Velocity Head}

The liquid wall must be thick enough to provide adequate shielding to chamber structures. Knowing that an equivalent thickness of flibe $\left(34 \% \mathrm{BeF}_{2}-66 \% \mathrm{LiF}\right)$ will provide adequate shielding by limiting neutron damage to less than 100 displacements per atom (DPA) after 30 years of continuous irradiation, we determined the thickness of each molten-salt that would result in an equivalent DPA.

Here, the chamber was assumed to be a spherical shell with inner radius of 0.5 meters. Starting from the first principles relation for power, we can derive a relation for the velocity head pumping power [10]:

$$
P=\frac{4}{6} \cdot \pi \cdot\left[\left(R_{p}+n_{s} \cdot \lambda_{n}\right)^{3}-R_{p}{ }^{3}\right] \cdot\left[\left(2 \cdot\left(R_{p}+\lambda_{n} \cdot n_{s}\right)\right) \cdot f\right]^{2} \cdot \rho \cdot f
$$

where $R_{p}$ is the inner radius of the molten-salt pocket, $\lambda_{\mathrm{n}}$ is the neutron mean free path at 2.54 MeV (mean energy of Atzeni target), $n_{s}$ is the number of mean free paths of liquid 
needed to adequately shield the chamber wall, $\rho$ is the liquid density (in $\mathrm{kg} / \mathrm{m}^{3}$ ), and $f$ is the frequency of shot repetition.

\section{Frictional/Minor Losses}

The pumping power needed to overcome frictional losses in the pipes is described by the equation:

$$
P=H \cdot \rho \cdot g \cdot Q
$$

where $\mathrm{Q}$ is the volumetric flow rate and $H$ is the frictional head loss and is given by Eqn. 3.

$$
H=\frac{\frac{1}{2} \cdot F \cdot(L / D)_{\text {eff }} \cdot u_{p i p e}{ }^{2}}{g}
$$

The frictional factor $\mathrm{F}$ is calculated using the Reynolds number as explained in [11]. The frictional losses for the original HYLIFE-II design as described by Palmer House are 7.84 MW [12]. Use of the high yield Atzeni target significantly reduces the required flow rate. This is mostly due to the lower repetition rate, which reduces the liquid velocity. The softer spectrum of the Atzeni target also leads to a thinner pocket $(45 \mathrm{~cm}$ vs. $56 \mathrm{~cm}$ ) and the overall frictional losses are only $1.83 \mathrm{MW}$.

\section{Lifting Power}


Lifting power is needed to get the liquid that has been sprayed to the bottom of the chamber back up to the top of the chamber. It is calculated using a 10.5-m distance from the bottom of the chamber to the top of the jets. The equation for the lifting power is:

$$
P=10.5 \cdot \rho \cdot g \cdot Q
$$

For the original HYLIFE-II design, the lift power was $10.98 \mathrm{MW}$. Using the values for the tritium-lean target results in a significant drop in the lifting pumping power to 4.68 MW (for flibe). In this case, the reduction is due entirely to the reduced flow rate.

\section{Pumping Power Results}

Sixty-six liquids were analyzed for the total pumping power needed to keep the salt flowing through the chamber at the correct frequency. Acceptable pumping power was assumed to be less than or equal to $80 \mathrm{MW}$, though the exact value is subject to debate. Nine liquids failed the pumping power requirement. Seven of them are high viscosity boron containing compounds. The other two are $\mathrm{BeF}_{2}$ and $\mathrm{Tl}_{2} \mathrm{~S}$, which are also very viscous substances. Materials that fared well in the pumping power assessment usually contained $\mathrm{Li}, \mathrm{Na}$, or $\mathrm{Rb}$. Some other materials also passed, but on a less frequent basis. Typical pumping power results are shown in reference [11].

\section{Conclusions and Recommendations}


Upon conclusion of the numerical analysis, approximately 57 liquids passed all evaluations. Most of these salts contain elements such as $\mathrm{Na}, \mathrm{Li}, \mathrm{Be}, \mathrm{B}, \mathrm{F}$, and O. Other elements were present in lesser frequency. These liquids are presented in Table II. It is recommended that further analysis be done on these liquids. Future assessments may include corrosion, surface tension, and/or vapor pressure studies. After additional screening, perhaps 6-12 materials might remain. A detailed analysis of these materials then could be conducted to assess their potential use in a thick-liquid, fast ignition inertial confinement fusion energy concept.

\section{Acknowledgements}

Work performed under the auspices of the US Department of Energy by University of California Lawrence Livermore National Laboratory under Contract W-7405-Eng-48.

\section{References}

1. M. Tabak et al., "Ignition and high gain with ultra powerful lasers", Phys. Plasmas 1 (5), (1994).

2. J. F. Latkowski et al., "Safety and Environmental Advantages of Using Tritium-Lean Targets for Inertial Fusion Energy," Proceedings of the First International Conference on Inertial Fusion Sciences and Applications (2000) 823-826.

3. S. Atzeni and M. L. Ciampi, "Burn performance of fast ignited, tritium-poor ICF fuels", Nucl. Fus. 37 (1997) 1665-1677. 
4. Moir R. W. et al., "HYLIFE-II - A Molten-Salt Inertial Fusion Energy Power Plant Design - Final Report", Fus. Tech., (1994), V25(N1):5-25.

5. NIST Properties of Molten Salts Database, Version 2, U. S. Dept. of Commerce, National Institute of Standards and Technology (1992).

6. D. E. Cullen, "TART98: A Coupled Neutron Photon 3-D, Combinatorial Geometry, Time Dependent, Monte Carlo Transport Code”, LLNL, UCRL-ID-126455, Rev. 2 (1998).

7. J. Sanz, "ACAB98: Activation Code for Fusion Applications. User's Manual V4.0", LLNL, UCRL-CR-133040 (1999).

8. S. A. Fetter, E. T. Cheng, and F. M. Mann, "Long-term radioactive waste from fusion reactors: Part II," Fus. Eng. Des., 13, 239-246, (1990).

9. S. Reyes et al., "Accident consequences analysis of the HYLIFE-II inertial fusion energy power plant design", Nucl. Inst. \& Meth. Phys. Res. A, 416-421, (2001).

10. R. C. Schmitt et al., "Liquid scoping study for tritium lean, fast ignition inertial fusion energy power plants," LLNL, UCRL-ID-144899, (2001).

11. B. R. Munson, D. F. Young, and T. H. Okiishi (1998), Fundamentals of Fluid Mechanics. Update Edition. John Wiley \& Sons, Inc.

12. P. A. House, "Hylife-II Reactor Chamber Design Refinements", Fus. Tech. 26 (1994) 1178-1195. 
Equation 1

$$
P=\frac{4}{6} \cdot \pi \cdot\left[\left(R_{p}+n_{s} \cdot \lambda_{n}\right)^{3}-R_{p}^{3}\right] \cdot\left[\left(2 \cdot\left(R_{p}+\lambda_{n} \cdot n_{s}\right)\right) \cdot f\right]^{2} \cdot \rho \cdot f
$$


Equation 2

$P=H \cdot \rho \cdot g \cdot Q$ 
Equation 3

$H=\frac{\frac{1}{2} \cdot F \cdot(L / D)_{e f f} \cdot u_{p i p e}{ }^{2}}{g}$ 
Equation 4

$$
P=10.5 \cdot \rho \cdot g \cdot Q
$$


Table I. Maximum density an element can have in a liquid in order to be acceptable for use in thick-liquid protection of the fusion chamber.

\begin{tabular}{|c|c|c|c|c|c|c|c|c|c|c|c|}
\hline Element & $\begin{array}{l}\text { Limit } \\
(g / c c)\end{array}$ & $\begin{array}{l}\text { Limiting } \\
\text { Factor }\end{array}$ & Element & $\begin{array}{l}\text { Limit } \\
(g / c c)\end{array}$ & $\begin{array}{l}\text { Limiting } \\
\text { Factor }\end{array}$ & Element & $\begin{array}{l}\text { Limit } \\
(g / c c)\end{array}$ & $\begin{array}{c}\text { Limiting } \\
\text { Factor }\end{array}$ & Element & $\begin{array}{l}\text { Limit } \\
(g / c c)\end{array}$ & $\begin{array}{l}\text { Limiting } \\
\text { Factor }\end{array}$ \\
\hline $\mathrm{Li}$ & $1.10 E+02$ & $\mathrm{AH}$ & v & $3.78 \mathrm{E}+02$ & $\mathrm{AH}$ & Ru & 7.41E-03 & WDR & $T b$ & $2.66 \mathrm{E}-05$ & WDR \\
\hline $\mathrm{Be}$ & $7.53 E+03$ & WDR & $\mathrm{Cr}$ & $1.41 \mathrm{E}+03$ & $\mathrm{AH}$ & $\mathrm{Rh}$ & 3.54E-02 & WDR & Dy & 1.60E-04 & WDR \\
\hline$B$ & $9.49 E+02$ & WDR & $\mathrm{Mn}$ & $1.46 \mathrm{E}+01$ & $\mathrm{AH}$ & $\mathrm{Pd}$ & 2.05E-03 & WDR & Ho & 3.75E-06 & WDR \\
\hline C & $8.34 \mathrm{E}+01$ & WDR & $\mathrm{Fe}$ & $4.54 \mathrm{E}+01$ & CDR & $\mathrm{Ag}$ & 9.04E-05 & WDR & $\mathrm{Er}$ & 4.64E-04 & WDR \\
\hline$N$ & 4.78E-02 & WDR & Co & 7.13E-04 & CDR & Cd & 2.88E-02 & WDR & $\mathrm{Tm}$ & 1.35E-02 & WDR \\
\hline 0 & $2.63 E+01$ & WDR & $\mathrm{Ni}$ & 1.02E-01 & CDR & In & $2.05 E+01$ & $\mathrm{AH}$ & $Y b$ & $1.64 E+01$ & WDR \\
\hline$F$ & $1.05 E+02$ & WDR & $\mathrm{Cu}$ & $1.85 \mathrm{E}-01$ & CDR & Sn & $1.63 E+01$ & WDR & Lu & $1.49 E+01$ & $\mathrm{AH}$ \\
\hline $\mathrm{Ne}$ & $1.22 E+01$ & WDR & $\mathrm{Zn}$ & $2.29 E+01$ & CDR & $\mathrm{Sb}$ & $2.00 E+00$ & $\mathrm{AH}$ & $\mathrm{Hf}$ & $1.25 E+01$ & $\mathrm{AH}$ \\
\hline $\mathrm{Na}$ & $5.11 E+01$ & CDR & $\mathrm{Ga}$ & $8.48 \mathrm{E}+00$ & $\mathrm{AH}$ & $\mathrm{Te}$ & 9.69E-01 & WDR & Ta & $1.25 E+00$ & $\mathrm{AH}$ \\
\hline $\mathrm{Mg}$ & $2.64 \mathrm{E}+01$ & $\mathrm{AH}$ & $\mathrm{Ge}$ & $1.18 E+02$ & $\mathrm{AH}$ & 1 & 2.90E+01 & $\mathrm{AH}$ & $w$ & $8.38 E+00$ & WDR \\
\hline $\mathrm{Al}$ & $3.45 \mathrm{E}-02$ & WDR & As & $2.51 E+00$ & $\mathrm{AH}$ & $\mathrm{Xe}$ & 9.83E-02 & CDR & $\mathrm{Re}$ & 4.93E-01 & WDR \\
\hline Si & $6.90 \mathrm{E}+01$ & WDR & $\mathrm{Se}$ & 5.51E-02 & WDR & Cs & 1.43E-02 & CDR & Os & $6.45 \mathrm{E}-03$ & WDR \\
\hline$P$ & $3.72 \mathrm{E}+\mathrm{O} 2$ & $\mathrm{AH}$ & $\mathrm{Br}$ & 1.13E-01 & WDR & $\mathrm{Ba}$ & 8.66E-02 & CDR & Ir & $9.80 \mathrm{E}-05$ & WDR \\
\hline$s$ & $2.06 \mathrm{E}+01$ & $\mathrm{AH}$ & $\mathrm{Kr}$ & 2.63E-01 & CDR & La & $1.15 \mathrm{E}+01$ & WDR & $\mathrm{Pt}$ & 7.33E-02 & WDR \\
\hline $\mathrm{Cl}$ & 4.90E-02 & WDR & $\mathrm{Rb}$ & $3.11 E \div 00$ & CDR & $\mathrm{Ce}$ & $1.29 \mathrm{E}+01$ & WDR & $\mathrm{Au}$ & $4.97 E+00$ & $\mathrm{AH}$ \\
\hline Ar & $6.45 \mathrm{E}-02$ & WDR & $\mathrm{Sr}$ & $7.29 E+01$ & CDR & $\mathrm{Pr}$ & 3.18E+01 & $\mathrm{AH}$ & $\mathrm{Hg}$ & $2.04 \mathrm{E}+02$ & $\mathrm{AH}$ \\
\hline $\mathrm{K}$ & 5.01E-02 & WDR & $Y$ & $8.38 E+00$ & $\mathrm{AH}$ & Nd & 9.82E-02 & CDR & $\mathrm{Tl}$ & $3.35 E+01$ & $\mathrm{AH}$ \\
\hline $\mathrm{Ca}$ & $1.34 E+00$ & WDR & $\mathrm{Zr}$ & $2.77 E+00$ & WDR & $\mathrm{Sm}$ & 7.78E-04 & CDR & $\mathrm{Pb}$ & $9.05 E+00$ & WDR \\
\hline Sc & $5.09 E+00$ & $\mathrm{AH}$ & $\mathrm{Nb}$ & 1.81E-05 & WDR & Eu & 4.76E-05 & CDR & $\mathrm{Bi}$ & $5.15 E-04$ & WDR \\
\hline $\mathrm{Ti}$ & $5.86 \mathrm{E}+01$ & $\mathrm{AH}$ & Mo & 3.32E-04 & WOR & Gd & 9.26E-04 & WDR & & & \\
\hline
\end{tabular}


Table II. Liquids that passed all assessments.

\begin{tabular}{|c|c|c|c|c|c|c|c|c|c|c|c|}
\hline \multicolumn{3}{|c|}{ Molten-Salt Composition } & \multicolumn{3}{|c|}{ Mol \% } & \multicolumn{3}{|c|}{ Molten-Salt Composition } & \multicolumn{3}{|c|}{ Mol \% } \\
\hline $\mathrm{BeF}_{2}$ & LiF & $\sim$ & 34 & 66 & 0 & $\mathrm{NaPO}_{3}$ & $\mathrm{Na}_{2} \mathrm{SO}_{4}$ & $\sim$ & 75 & 25 & 0 \\
\hline $\mathrm{BeF}_{2}$ & LiF & $\sim$ & 50 & 50 & 0 & $\mathrm{NaPO}_{3}$ & $\mathrm{Na}_{4} \mathrm{P}_{2} \mathrm{O}_{7}$ & $\sim$ & 75 & 25 & 0 \\
\hline $\mathrm{BeF}_{2}$ & LiF & $\sim$ & 75 & 25 & 0 & $\mathrm{NaVO}_{3}$ & $\sim$ & $\sim$ & 100 & 0 & 0 \\
\hline $\mathrm{BeF}_{2}$ & $\mathrm{NaF}$ & $\sim$ & 30 & 70 & 0 & $\mathrm{NaVO}_{3}$ & $\mathrm{~V}_{2} \mathrm{O}_{5}$ & $\sim$ & 20 & 80 & 0 \\
\hline $\mathrm{BeF}_{2}$ & $\mathrm{NaF}$ & $\sim$ & 50 & 50 & 0 & $\mathrm{NaVO}_{3}$ & $\mathrm{~V}_{2} \mathrm{O}_{5}$ & $\sim$ & 80 & 20 & 0 \\
\hline $\mathrm{BeF}_{2}$ & $\mathrm{RbF}$ & $\sim$ & 50 & 50 & 0 & $\mathrm{Na}_{2} \mathrm{CO}_{3}$ & $\sim$ & $\sim$ & 100 & 0 & 0 \\
\hline $\mathrm{CaSO}_{4}$ & $\mathrm{Na}_{2} \mathrm{SO}_{4}$ & $\sim$ & 10 & 90 & 0 & $\mathrm{Na}_{2} \mathrm{SO}_{4}$ & $\sim$ & $\sim$ & 100 & 0 & 0 \\
\hline $\mathrm{CaSO}_{4}$ & $\mathrm{Na}_{2} \mathrm{SO}_{4}$ & $\sim$ & 30 & 70 & 0 & $\mathrm{Na}_{2} \mathrm{~S}_{3}$ & $\sim$ & $\sim$ & 100 & 0 & 0 \\
\hline $\mathrm{CaSO}_{4}$ & $\mathrm{Na}_{2} \mathrm{SO}_{4}$ & $\sim$ & 55 & 45 & 0 & $\mathrm{Na}_{2} \mathrm{~S}_{4}$ & $\sim$ & $\sim$ & 100 & 0 & 0 \\
\hline $\mathrm{FeS}$ & $\sim$ & - & 100 & 0 & 0 & $\mathrm{Na}_{2} \mathrm{~S}_{5}$ & $\sim$ & $\sim$ & 100 & 0 & 0 \\
\hline $\mathrm{Hgl}_{2}$ & - & $\sim$ & 100 & 0 & 0 & $\mathrm{Na}_{2} \mathrm{WO}_{4}$ & $\sim$ & $\sim$ & 100 & 0 & 0 \\
\hline LiF & $\sim$ & $\sim$ & 100 & 0 & 0 & $\mathrm{Na}_{4} \mathrm{P}_{2} \mathrm{O}_{7}$ & $\sim$ & $\sim$ & 100 & 0 & 0 \\
\hline LiF & $\mathrm{NaF}$ & $\mathrm{BeF}_{2}$ & 33.3 & 33.3 & 33.4 & $\mathrm{Na}_{4} \mathrm{P}_{2} \mathrm{O}_{7}$ & $\mathrm{WO}_{3}$ & $\sim$ & 34 & 66 & 0 \\
\hline LiF & $\mathrm{NaF}$ & $\mathrm{BeF}_{2}$ & 31.5 & 31 & 37.5 & $\mathrm{Na}_{4} \mathrm{P}_{2} \mathrm{O}_{7}$ & $\mathrm{WO}_{3}$ & $\sim$ & 65 & 35 & 0 \\
\hline LiF & $\mathrm{NaF}$ & $\mathrm{BeF}_{2}$ & 63 & 5 & 32 & $\mathrm{RbF}$ & $\sim$ & $\sim$ & 100 & 0 & 0 \\
\hline LiF & $\mathrm{NaF}$ & $\sim$ & 60 & 40 & 0 & Rbl & $\sim$ & $\sim$ & 100 & 0 & 0 \\
\hline LiF & $\mathrm{RbF}$ & $\sim$ & 43 & 57 & 0 & $\mathrm{Rb}_{2} \mathrm{CO}_{3}$ & $\sim$ & $\sim$ & 100 & 0 & 0 \\
\hline Lil & $\sim$ & $\sim$ & 100 & 0 & 0 & TII & $\sim$ & $\sim$ & 100 & 0 & 0 \\
\hline $\mathrm{Li}_{2} \mathrm{CO}_{3}$ & $\sim$ & $\sim$ & 100 & 0 & 0 & $\mathrm{~V}_{2} \mathrm{O}_{5}$ & $\sim$ & $\sim$ & 100 & 0 & 0 \\
\hline $\mathrm{Li}_{2} \mathrm{CO}_{3}$ & $\mathrm{Na}_{2} \mathrm{CO}_{3}$ & $\sim$ & 10 & 90 & 0 & $\mathrm{PbF}_{2}$ & $\sim$ & $\sim$ & 100 & 0 & 0 \\
\hline $\mathrm{Li}_{2} \mathrm{CO}_{3}$ & $\mathrm{Na}_{2} \mathrm{CO}_{3}$ & $\sim$ & 40 & 60 & 0 & $\mathrm{Rb}$ & $\sim$ & $\sim$ & 100 & 0 & 0 \\
\hline $\mathrm{Li}_{2} \mathrm{CO}_{3}$ & $\mathrm{Na}_{2} \mathrm{CO}_{3}$ & $\sim$ & 60 & 40 & 0 & $\mathrm{LiPb}$ & $\sim$ & $\sim$ & 100 & 0 & 0 \\
\hline $\mathrm{Li}_{2} \mathrm{CO}_{3}$ & $\mathrm{Na}_{2} \mathrm{CO}_{3}$ & $\sim$ & 90 & 10 & 0 & $\mathrm{Na}$ & $\sim$ & $\sim$ & 100 & 0 & 0 \\
\hline $\mathrm{Li}_{2} \mathrm{WO}_{4}$ & $\sim$ & $\sim$ & 100 & 0 & 0 & $\mathbf{L i}$ & $\sim$ & $\sim$ & 100 & 0 & 0 \\
\hline $\mathrm{NaBF}_{4}$ & $\sim$ & $\sim$ & 100 & 0 & 0 & $\mathrm{Hg}$ & $\sim$ & $\sim$ & 100 & 0 & 0 \\
\hline $\mathrm{NaBF}_{4}$ & $\mathrm{NaF}$ & $\sim$ & 92 & 8 & 0 & Ġa & $\sim$ & $\sim$ & 100 & 0 & 0 \\
\hline $\mathrm{NaF}$ & $\sim$ & $\sim$ & 100 & 0 & 0 & LiSn & $\sim$ & $\sim$ & 100 & 0 & 0 \\
\hline $\mathrm{Nal}$ & $\sim$ & $\sim$ & 100 & 0 & 0 & $\ln$ & $\sim$ & $\sim$ & 100 & 0 & 0 \\
\hline $\mathrm{NaPO}_{3}$ & $\sim$ & $\sim$ & 100 & 0 & 0 & & & & & & \\
\hline
\end{tabular}

